\title{
Pengaruh Daya Tarik Iklan di Media Sosial Instagram terhadap Minat Beli Konsumen (Survei Terhadap Produk Sepatu Brodo di Kalangan
}

\section{Anak Muda Jakarta Barat)}

\author{
Hendy Suryawijaya, Farid Rusdi \\ hesuwi@gmail.com, farid@,fikom.untar.ac.id
}

Fakultas Ilmu Komunikasi Universitas Tarumanagara

\begin{abstract}
The attractiveness of advertising can be assumed as something that moves people, talks about their wants or needs, and arouses their interest. The attractiveness of advertising is very important because it will increase the success of communication with consumers. An ad with a high ad appeal can create consumer buying interest towards a brand. buying interest is an impulse in a person to pay attention without coercion on a product and lead to a purchase. This study aims to measure the effect of the attractiveness of advertising on social media on consumer buying interest. This study uses quantitative techniques with survey methods and uses Brodo as an observation unit. Primary data was collected through distributing questionnaires to 105 young respondents in the West Jakarta area who had seen or known Brodo shoes advertisements in the form of posts or stories on Instagram social media. Data analysis uses Statistical Package for the Social Sciences with SPSS for Windows 17 application. Based on the results of the study, it is known that there is a positive influence between the attractiveness of advertising on social media on consumer buying interest in products from Brodo shoes. The attractiveness of advertising has an influence of $66.6 \%$ on buying interest. If the attractiveness of advertisements increases, consumers' buying orders will also increase. Conversely, if the attractiveness of advertising decreases, consumers' buying orders will also decrease.
\end{abstract}

Keywords: advertising appeal, buying interest, brodo, social media

\begin{abstract}
Abstrak
Iklan memiliki daya tarik. Melalui iklan orang dapat "tergerak" untuk berbicara baik tentang keinginan maupun kebutuhan mereka, dan pada akhirnya membangun ketertarikan terhadap produk tertentu. Daya tarik iklan dinilai penting karena dapat menghasilkan komunikasi yang sukses dengan konsumen. Suatu iklan dengan daya tarik iklan yang tinggi dapat menciptakan minat beli konsumen terhadap suatu merek. minat beli merupakan dorongan dalam diri seseorang untuk menaruh perhatian tanpa paksaan pada suatu produk dan berujung pada pembelian. Penelitian ini bertujuan untuk mengukur pengaruh daya tarik iklan di media sosial terhadap minat beli konsumen. Teknik yang digunakan dalam penelitian adalah kuantitatif tepatnya metode survey, dan menggunakan Brodo sebagai unit observasi. Data penelitian didapat dengan membagikan kuesioner kepada 105 responden anak muda di daerah Jakarta Barat yang pernah melihat atau mengetahui iklan sepatu Brodo baik dalam bentuk postingan atau story di media sosial Instagram. Analisis data menggunakan Statistical Package for the Social Sciences dengan aplikasi SPSS for windows 17. Berdasarkan hasil penelitian, diketahui bahwa ada pengaruh yang positif antara daya tarik iklan di media sosial terhadap minat beli konsumen terhadap produk dari sepatu Brodo. Daya tarik iklan berpengaruh terhadap minat beli sebesar $66,6 \%$. Artinya, jika daya tarik iklan meningkat maka mendorong meningkatnya niat beli konsumen. Sebaliknya, jika daya tarik iklan menurun maka mendorong turunnya minat beli konsumen.
\end{abstract}

Kata kunci: brodo, daya tarik iklan, minat beli, media sosial 
Hendy Suryawijaya, Farid Rusdi: Pengaruh Daya Tarik Iklan di Media Sosial Instagram terhadap Minat Beli Konsumen (Survei Terhadap Produk Sepatu Brodo di Kalangan Anak Muda Jakarta Barat)

\section{Pendahuluan}

Iklan kini menjadi bagian penting dalam strategi pemasaran pada suatu perusahaan. Menurut Kotler \& Kevin, definisi periklanan sendiri adalah berbagai bentuk penyajian nonpersonal dan promosi barang, ide, barang atau jasa oleh sebuah sponsor tertentu yang harus dibayar (dalam Sari, 2016). Pada zaman sekarang iklan dapat dikategorikan sebagai sarana yang paling efektif untuk meningkatkan penjualan dari produk atau merek tertentu. Hal ini mendorong para pemasar-pemasar di luar sana untuk bersaing dalam membuat iklan yang kreatif dan unik.

Iklan terus berkembang dari waktu ke waktu dan perkembangan ini menciptakan suatu daya tarik yang dapat mendorong rasa ingin tahu dari penerimanya. Morissan (2014:342) mengemukakan daya tarik iklan dapat dikatakan sebagai pendorong yang menarik orang untuk "tergerak" dalam mengemukakan baik keinginan maupun kebutuhan mereka, dan pada akhirnya membangun ketertarikan mereka terhadap produk tertentu.

Menurut Indriani \& Hendiarti, daya tarik iklan dinilai penting karena dapat memastikan komunikasi yang sukses dengan konsumen (dalam Gusmanto \& Hasibuan, 2014). Perusahaan-perusahaan terdorong untuk menciptakan iklan yang kreatif dan unik supaya iklan yang mereka sampaikan memiliki daya tarik yang dapat membangun ketertarikan konsumen dan preferensi konsumen terhadap produk yang mereka jual. Hal ini disebabkan karena iklan dengan penyampaian yang kreatif dan berbeda dari yang lain dapat mempengaruhi pikiran konsumen terhadap merek tertentu. Daya tarik iklan juga dapat didefinisikan sebagai pendekatan yang digunakan para pemasar untuk menarik perhatian dan rasa ingin tahu dari konsumen, sehingga mempengaruhi perasaan konsumen terhadap suatu produk (dalam Ardiansyah, Arifin \& Fanani, 2015).

Tidak seperti pada iklan di televisi, iklan di internet maupun media sosial akan muncul terus-menerus tanpa dibatasi oleh waktu. Salah satu media sosial yang sering dikunjungi dan memuat banyak iklan adalah Instagram. Instagram sekarang dapat menampilkan iklan baik di timeline (beranda) penggunanya maupun di Instagram story. Iklan di Instagram lebih di kenal dengan sebutan Instagram ads. Indriarto dalam Hastuti (2013) menyatakan bahwa iklan dengan cakupan media yang lebih luas serta frekuensi tayang yang lebih tinggi dapat mendorong konsumen untuk lebih memahami informasi dan pesan dari iklan yang disampaikan.

Suatu iklan dengan daya tarik iklan yang tinggi dapat menimbulkan minat beli terhadap suatu merek yang tinggi pula. Mowen (1995) dalam Meldarianda \& Lisan (2010) menyatakan bahwa minat beli ditunjukkan dari kecenderungan konsumen dalam mengambil tindakan pembelian terhadap suatu merek, dan kecenderungan ini dapat diukur melalui frekuensi pembelian konsumen terhadap merek tersebut. Menurut Blackwell \& Engel (2008), minat beli merupakan dorongan dalam diri seseorang untuk menaruh perhatian tanpa paksaan pada suatu produk dan berujung pada pembelian dalam (Ningrum, 2016).

Brodo merupakan perusahaan yang menjual pakaian pria berbasis retail dan ecommerce. Perusahaan ini berlokasi di Bandung, Jawa Barat. Brodo sendiri menawarkan banyak sekali produk fashion pria, antara lain: sepatu, dompet, kaos, celana, tas, sneakers dan juga aksesoris pria lainnya. Produk andalan dari Brodo yang sering diperbincangkan adalah sepatu kulit. Brodo dulunya bernama Brodo Foorwear didirikan oleh dua orang mahasiswa Teknik Sipil dan Lingkungan Institut Teknologi Bandung (ITB), Yukka Harlanda sebagai CEO dan Putera Dwi Karunia sebagai COO, sejak tahun 2010.

Kemudian Brodo mulai memasarkan produknya di Instagram melalui Instagram $a d s$. Situs tersebut menurut mereka juga menjadi media pemasaran yang sangat efektif karena dapat menarik perhatian masyarakat banyak dengan sangat cepat. 
Berdasarkan penjelasan latar belakang di atas, penulis ingin meneliti lebih lanjut apakah ada pengaruh daya tarik iklan di media sosial terhadap minat beli konsumen.

\section{Metode Penelitian}

Peneliti menggunakan penelitian kuantitatif dalam penelitian ini, tepatnya dengan metode survei. Metode survei dilakukan dengan cara mengumpulkan data atau informasi melalui pengajuan daftar pertanyaan yang kemudian akan dijawab oleh para responden. Data dapat diperoleh peneliti melalui penyebaran kuesioner dan wawancara terhadap responden (Sujarweni, 2014:8). Populasi adalah objek maupun subjek dengan suatu karakteristik tertentu sesuai dengan kriteria penelitian yang akan diteliti untuk mencapai suatu kesimpulan (Sugiyono, 2017:80).

Populasi yang diteliti oleh peneliti adalah seluruh masyarakat yang pernah melihat atau mengetahui iklan sepatu Brodo baik dalam bentuk postingan atau story di media sosial Instagram.

Sampel adalah sebagian obyek atau subyek dari populasi yang dapat mewakili seluruh responden yang digunakan dalam penelitian. Karena ada beberapa keterbatasan, peneliti tidak mungkin menggunakan seluruh populasi untuk diteliti, melainkan menggunakan sampel. Kesimpulan dari hasil penelitian terhadap sampel akan dianggap sama dengan populasi (Sujarweni, 2019:65). Dalam penelitian ini, sampel yang diteliti oleh penulis adalah anak muda di daerah Jakarta Barat yang pernah melihat atau mengetahui iklan sepatu Brodo baik dalam bentuk postingan atau story di media sosial Instagram.

Peneliti menggunakan teori Roscoe untuk menentukan jumlah sampel minimum yang diperlukan di penelitian, tepatnya jumlah indikator dikali 5. Peneliti membagikan kuesioner penelitian kepada 105 responden anak muda di daerah Jakarta Barat yang pernah melihat atau mengetahui iklan sepatu Brodo baik dalam bentuk postingan atau story di media sosial Instagram melalui google form untuk mendapatkan data sesuai dengan yang diharapkan oleh peneliti.

Peneliti menggunakan teknik nonprobability sampling dengan pendekatan purposive sampling untuk penelitian ini. Nonprobability sampling sendiri adalah sebuah teknik untuk mengambil sampel dari populasi dimana setiap anggota dari populasi tidak memiliki peluang yang sama untuk dipilih sebagai sampel penelitian (Sujarweni, 2019:71). Dalam penelitian ini diukur menggunakan skala likert dengan bantuan software SPSS ver. 17 untuk menguji validitas, reabilitas, dan hipotesis.

\section{Hasil Penelitian dan Diskusi}

Dalam penelitian ini, peneliti menyebarkan kuesioner kepada sebanyak 105 responden dan mendapatkan data berupa jenis kelamin responden, yaitu sebanyak 75 responden $(71,4 \%)$ berjenis kelamin laki-laki, dan sebanyak 30 responden $(28,6 \%)$ berjenis kelamin perempuan. Kemudian untuk usia di dominasi pada umur $21-24$ Tahun dengan total 52 responden $(49,5 \%), 18$ - 20 Tahun dengan total 28 responden $(26,7 \%)$ dan diatas 24 Tahun sebanyak 25 responden $(23,8 \%)$. Setelah melakukan uji validitas dengan menggunakan aplikasi SPSS for windows ver 17, maka berikut adalah hasil dari uji validitas. 
Hendy Suryawijaya, Farid Rusdi: Pengaruh Daya Tarik Iklan di Media Sosial Instagram terhadap Minat Beli Konsumen (Survei Terhadap Produk Sepatu Brodo di Kalangan Anak Muda Jakarta Barat)

Tabel 1. Uji Validitas

\begin{tabular}{|c|c|c|c|}
\hline Yariabel & Butir Indikator & $\begin{array}{l}\text { Corrected } \\
\text { Item Total } \\
\text { Correlation }\end{array}$ & Keterangan \\
\hline \multirow{11}{*}{$\begin{array}{l}\text { Daya Tarik } \\
\text { Iklan } \\
\text { (X) }\end{array}$} & $\mathrm{X} 1$ & 0,673 & Valid \\
\hline & $\mathrm{X} 2$ & 0,647 & Valid \\
\hline & $\mathrm{X} 3$ & 0,668 & Valid \\
\hline & $\mathrm{X} 4$ & 0,694 & Valid \\
\hline & $\mathrm{X} 5$ & 0,634 & Valid \\
\hline & $\mathrm{X} 6$ & 0,677 & Valid \\
\hline & $\mathrm{X} 7$ & 0,710 & Valid \\
\hline & $\mathrm{X} 8$ & 0,688 & Valid \\
\hline & $\mathrm{X9}$ & 0,680 & Valid \\
\hline & $\mathrm{X} 10$ & 0,677 & Valid \\
\hline & $\mathrm{X} 11$ & 0,684 & Valid \\
\hline \multirow{10}{*}{$\begin{array}{l}\text { Minat Beli } \\
\text { (Y) }\end{array}$} & MB1 & 0,605 & Valid \\
\hline & MB2 & 0,713 & Valid \\
\hline & MB3 & 0,662 & Valid \\
\hline & MB4 & 0,620 & Valid \\
\hline & MB5 & 0,748 & Valid \\
\hline & MB6 & 0,766 & Valid \\
\hline & MB7 & 0,726 & Valid \\
\hline & MB8 & 0,712 & Valid \\
\hline & MB9 & 0,639 & Valid \\
\hline & MB10 & 0,518 & Valid \\
\hline
\end{tabular}

Sumber: Hasil Pengolahan Data SPSS Ver 17

Tabel 1, menunjukkan bahwa butir-butir indikator pernyataan dari seluruh variabel dinyatakan valid seluruhnya karena memiliki angka korelasi di atas 0,2.

Tabel 2. Uji Reliabilitas

\begin{tabular}{|c|c|c|}
\hline Variabel & Nilai Cronbach's Alpha & Keterangan \\
\hline Dava Tarik Iklan (X) & 0,916 & Reliabel \\
\hline Minat Beli (Y) & 0,907 & Reliabel \\
\hline
\end{tabular}

Sumber: Hasil Pengolahan Data SPSS Ver 17

Tabel 2, menunjukkan bahwa setiap pernyataan dalam kuisoner dikatakan reliabel karena memiliki nilai Cronbach's Alpha di atas 0,6.

Tabel 3. Uji Normalitas

One-Sample Kolmogorov-Smirnov Test

\begin{tabular}{|c|c|c|c|}
\hline & & TX & TY \\
\hline \multirow{3}{*}{ Normal Parameters ${ }^{\mathrm{a}, \mathrm{b}}$} & $\mathrm{N}$ & 105 & 105 \\
\hline & Mean & 45.1619 & 40.6000 \\
\hline & Std. Deviation & 6.37019 & 5.76561 \\
\hline \multirow[t]{5}{*}{ Most Extreme Differences } & Absolute & .156 & .173 \\
\hline & Positive & .121 & .089 \\
\hline & Negative & -.156 & -173 \\
\hline & Kolmogorov-Smirnov Z & 1.603 & 1.771 \\
\hline & Asymp Sig. (2-tailed) & .112 & .064 \\
\hline
\end{tabular}

Sumber: Hasil Pengolahan Data SPSS Versi 17.0 
Dalam penelitian ini, peneliti menggunakan uji One Sample Kolmogorov Smirnov yang ada pada aplikasi SPSS Ver 15. Hasil analisis pada tabel 3 menunjukan bahwa ada nilai signifikansi sebesar 0,112 untuk variabel $\mathrm{X}$ dan 0,064 untuk variabel $\mathrm{Y}$. Hasil tersebut menyatakan bahwa distribusi data berdistribusi secara normal karena nilai signifikansi $\mathrm{X}$ dan $\mathrm{Y}>0,05$.

Tabel 4. Hasil Uji T

\begin{tabular}{|c|c|c|c|c|c|c|}
\hline \multirow{2}{*}{\multicolumn{2}{|c|}{ Model }} & \multicolumn{2}{|c|}{ Unstandardized Coefficients } & \multirow{2}{*}{$\begin{array}{c}\begin{array}{c}\text { Standardized } \\
\text { Coefficients }\end{array} \\
\text { Beta }\end{array}$} & \multirow[b]{2}{*}{$\mathrm{t}$} & \multirow[b]{2}{*}{ Sig. } \\
\hline & & B & Std. Error & & & \\
\hline \multirow[t]{2}{*}{1} & (Constant) & 7.246 & 2.351 & & 3.082 & .003 \\
\hline & TX & .739 & .052 & .816 & 14.325 & .000 \\
\hline
\end{tabular}

Sumber: Hasil Pengolahan Data SPSS Versi 17.0

Tabel 4 menunjukkan dari hasil analisis data diketahui bahwa nilai $\mathrm{t}=14,325$ dan tingkat signifikansi $=0,000<0,05$. Karena nilai $\mathrm{p}<0,05$, maka $\mathrm{H}_{0}$ ditolak dan Ha diterima, yang berarti terdapat pengaruh positif daya tarik iklan terhadap minat beli konsumen.

Tabel 5. Hasil Uji Regresi Linear Sederhana

\begin{tabular}{|c|c|c|c|c|c|c|}
\hline \multirow{2}{*}{\multicolumn{2}{|c|}{ Model }} & \multicolumn{2}{|c|}{ Unstandardized Coefficients } & \multirow{2}{*}{$\begin{array}{c}\text { Standardized } \\
\text { Coefficients } \\
\text { Beta }\end{array}$} & \multirow[b]{2}{*}{$\mathrm{t}$} & \multirow[b]{2}{*}{ Sig. } \\
\hline & & B & Std. Error & & & \\
\hline \multirow[t]{2}{*}{1} & (Constant) & 7.246 & 2.351 & & 3.082 & .003 \\
\hline & TX & .739 & .052 & .816 & 14.325 & .000 \\
\hline
\end{tabular}

Sumber: Hasil Pengolahan Data SPSS Versi 17.0

Dengan keterangan $\mathrm{Y}=$ Minat Beli dan $\mathrm{X}=$ Daya Tarik Iklan. Berdasarkan persamaan regresi linear pada tabel 5, dapat diuraikan sebagai berikut:

1. Nilai Y (Minat Beli) akan tetap sebesar 7,246 konstanta jika nilai X (Daya Tarik Iklan) tidak mengalami perubahan, baik peningkatan maupun penurunan.

2. Jika nilai X (Daya Tarik Iklan) mengalami peningkatan nilai sebesar 1 satuan, maka nilai Y (Minat Beli) akan mengalami peningkatan sebesar 0,739 menjadi 7,985.

Tabel 6. Hasil Uji Koefisien Korelasi

\begin{tabular}{|c|c|c|c|c|}
\hline Model & $\mathrm{R}$ & R Square & $\begin{array}{l}\text { Adjusted R } \\
\text { Square }\end{array}$ & $\begin{array}{c}\text { Std. Error of the } \\
\text { Estimate }\end{array}$ \\
\hline 1 & $.816^{\mathrm{a}}$ & .666 & .663 & 3.34916 \\
\hline
\end{tabular}

Sumber: Hasil Pengolahan Data SPSS Ver 15

Dari hasil perhitungan tabel 6, diketahui bahwa nilai koefisien korelasi R sebesar 0,816 yang berada di antara interval $0,80-0,100$ artinya daya tarik iklan mempunyai hubungan yang cukup kuat terhadap minat beli konsumen. 
Tabel 7. Hasil Uji Determinasi

\begin{tabular}{|l|r|r|r|r|}
\hline Model & \multicolumn{1}{|c|}{$\mathrm{R}$} & $\mathrm{R}$ Square & \multicolumn{1}{c|}{$\begin{array}{c}\text { Adjusted R } \\
\text { Square }\end{array}$} & $\begin{array}{c}\text { Std. Error of the } \\
\text { Estimate }\end{array}$ \\
\hline 1 & $.816^{\mathrm{a}}$ & .666 & .663 & 3.34916 \\
\hline
\end{tabular}

Sumber: Hasil Pengolahan Data SPSS Ver 15

Dari hasil perhitungan tabel 7, diketahui bahwa nilai koefisien determinasi pada tabel R Square sebesar 0,666 menunjukkan bahwa $66,6 \%$ minat beli dipengaruhi oleh daya tarik iklan sementara sisanya 33,4\% (100\%-66,6\%) dipengaruhi oleh faktor lain.

\section{Kesimpulan}

Hasil penelitian yang dilakukan oleh peneliti menunjukkan bahwa ada hubungan antara daya tarik iklan di media sosial terhadap minat beli konsumen yang berupa hubungan cukup kuat. Berdasarkan hasil uji koefisien korelasi, diketahui bahwa nilai korelasi berada di antara interval 0,80 - 0,100 yang menunjukkan bahwa daya tarik iklan memiliki pengaruh yang cukup kuat terhadap minat beli konsumen dan bernilai positif. Dengan demikian, semakin tinggi daya tarik iklan maka dapat mendorong minat beli konsumen untuk meningkat. Sebaliknya bila daya tarik suatu iklan menurun maka minat beli konsumen juga akan menurun.

Berdasarkan kuesioner yang telah disebarkan, data pernyataan sebanyak 21 butir pernyataan dinyatakan valid, karena semua pernyataan yang telah disebarkan mendukung pernyataan bahwa ada pengaruh antara daya tarik iklan di media sosial terhadap minat beli konsumen.

\section{Ucapan Terima Kasih}

Pada bagian ini, peneliti mau memberikan ucapan terima kasih kepada Fakultas Ilmu Komunikasi Universitas Tarumanagara, para responden, keluarga, teman-teman, dan seluruh pihak yang membantu penulis dalam menyelesaikan penelitian ini.

\section{Daftar Pustaka}

Ardiansyah, L., Arifin, Z., \& Fanani, D. (2015). Pengaruh Daya Tarik Iklan Terhadap Efektivitas Iklan (Survei Terhadap Iklan Honda Versi Band Nidji “One Heart"). Jurnal Administrasi Bisnis Vol. 23 No. 2.75 - 83.

Gusmanto \& Hasibuan, R. (2014). Analisis Pengaruh Citra Merek, Persepsi Harga, dan

Daya Tarik Iklan Terhadap Minat Beli Konsumen Pada Produk Air Minum Dalam Kemasan (AMDK) Galon Merek Aqua. Jurnal Bening Prodi Manajemen Vol. 1 No. $1.1-40$.

Hastuti, S. (2013). Efektivitas Iklan Layanan Masyarakat di Televisi. Jurnal Ilmu Komunikasi FISIP Universitas Riau Vol. 2 No. 2. 67 - 72.

Meldarianda, R. \& Henky, L. S. (2010). Pengaruh Store Atmosphere Terhadap Minat Beli Konsumen Pada Resort Café Atmosphere Bandung. Jurnal Bisnis dan Ekonomi (JBE), September 2010, Hal. 97 - 108.

Morissan. (2014). Periklanan: Komunikasi Pemasaran Terpadu. Jakarta: Kencana. 
Vol. 5, No. 1, Maret 2021, Hal 60-66

Ningrum, I.T.J., \& Nilowardono, S. (2016). Pengaruh Event dan Brand Image Terhadap Minat Beli Produk Rokok Sampoerna A Mild Pada PT HM Sampoerna Area Marketing Surabaya. Jurnal Manajemen Kinerja. Vol. 2, No. 1, Hal. 57-69.

Sugiyono. (2017). Metode Penelitian Kuantitatif, Kualitatif, dan $R$ dan D. Bandung: Alfabeta.

Sujarweni, Wiratna. (2019). Metodologi Penelitian. Yogyakarta: PT. Pustaka Baru. 